\title{
A New Diagnostic Test for Gaucher Disease Suitable for Population Screening
}

\author{
Sameer A. Sakallah, ${ }^{1}$ Carol Sansieri, ${ }^{1}$ David W. Kopp, ${ }^{1}$ David L. Cooper, ${ }^{1}$ and \\ John A. Barranger ${ }^{2}$
}

${ }^{1}$ Department of Pathology, Division of Molecular Diagnostics, University of Pittsburgh Medical Center; ${ }^{2}$ Department of Human Genetics, University of Pittsburgh, Pittsburgh, Pennsylvania 15261

\begin{abstract}
A new test for the diagnosis of Gaucher disease is described. The test is designed to screen large numbers of clinical specimens from high-risk populations. It consists of duplex PCR amplification of genomic DNA followed by hybridization to alkaline phosphatase-conjugated allele-specific oligonucleotide probes (ASOs). High melting temperature PCR primers were used to increase specificity and eliminate the need for a separate annealing step. All hybridization and washing steps were performed at one temperature. Chemiluminescent detection of signals is fast, and results are easily interpreted directly from $x$-ray films. Currently, the test is being used in our laboratories to screen Ashkenazi Jewish populations in whom Gaucher disease is common.
\end{abstract}

Gauch storage disease caused by mutations in the gene coding glucocerebrosidase..$^{(1-3)}$ The most common variant of the disease is type 1 , which has an incidence rate of 1 in 40,000 and a carrier frequency of 1 in 100. In the Ashkenazi Jewish population the carrier rate is 1 in 10 , and $\sim 1$ in 450 persons is affected. ${ }^{(4)}$ The disease is suspected in patients with painless splenomegaly, and diagnosis is confirmed by measurement of glucocerebrosidase activity in leukocytes, fibroblasts, amniocytes, or chorionic villi. Most carriers of GD (heterozygotes) have enzyme levels of $50 \%$ of normal values. However, in $20 \%$ of obligate heterozygotes, carrier detection by enzyme assay has proved unreliable. ${ }^{(1)}$

Several PCR-based methods for the detection of GD mutations have been described in recent years. These generally fall into two categories: PCR-mediated mutation detection ${ }^{(5)}$ or hybridization of allele-specific oligonucleotide probes (ASOs) to PCR-amplified genomic regions that contain loci for these mutations. ${ }^{(6)}$ PCR-mediated mutation detection methods are lengthy and expensive and are not suitable for largescale population screening. The ASO approach, however, is simpler, faster, and relatively inexpensive.

In this report we describe a new test for detection of the $\mathrm{N} 370 \mathrm{~S},{ }^{(7)} 84 \mathrm{gg},{ }^{(8)}$ L444P, ${ }^{(9)}$ and IVS2 $+1^{(10,11)}$ mutations. The test involves a two-temperature duplex PCR reaction followed by isothermal dot blot hybridization using alkaline phosphatase-conjugated ASOs. It is specifically designed for population screening and will identify $>95 \%$ of heterozygote carriers as well as compound heterozygotes. Starting with DNA extracted from whole blood, the test takes 1 day to finish and the results are easily interpretable.

\section{MATERIALS AND METHODS DNA Extraction from Whole Blood}

Whole blood samples $(200 \mu \mathrm{l})$ were diluted with $1 \mathrm{ml}$ of distilled water and mixed by gentle inversion for $45 \mathrm{~min}$ at room temperature. The tubes were centrifuged at low speed $(4500 \mathrm{rpm})$ in a microcentrifuge for $3 \mathrm{~min}$ at $4^{\circ} \mathrm{C}$. Cell pellets were washed once with $1 \mathrm{ml}$ of distilled water followed by one to two times in $1 \mathrm{ml}$ of Dulbecco's PBS. Pellets were resuspended and mixed with $250 \mu \mathrm{l}$ of $5 \%$ Chelex 100 suspension (Bio-Rad, Hercules, CA), incubated at $56^{\circ} \mathrm{C}$ for $1 \mathrm{hr}$, vortexed, and boiled for $10 \mathrm{~min}$. The Chelex resin was removed by centrifugation at high speed $(14,000 \mathrm{rpm})$ in a microcentrifuge for $3 \mathrm{~min}$, and DNA preparations $(\sim 5 \mu \mathrm{g})$ were stored at $4^{\circ} \mathrm{C}$. Of these preparations, $20-25 \mu \mathrm{l}(\sim 500 \mathrm{ng}$ DNA) was used in 50- $\mu$ l PCR reactions.

\section{Oligonucleotide Synthesis and Purification}

PCR primers were synthesized on a Cruachem P250 DNA synthesizer (Cruachem, Sterling, VA), and purified on Sep-Pak columns (Millipore, Milford, MA) using the manufacturer's instructions, and their sizes were verified by electrophoresis of ${ }^{32} \mathrm{P}$-end-labeled oligonucleotides on $20 \%$ denaturing polyacrylamide gels. Alkaline phosphataseconjugated hybridization probes (Table 1) were custom synthesized by Synthetic Genetics (San Diego, CA). 
TABLE 1 Hybridization Probes

\begin{tabular}{ll}
\hline $\begin{array}{l}\text { Hybridization } \\
\text { probes }\end{array}$ & Sequence \\
\hline 370 normal & CCTAGAACCTCCTGT \\
370 mutant & CCTAGAGCCTCCTG \\
444 normal & AACGACCTGGACGC \\
444 mutant & ACGACCCGGACGC \\
84gg normal & CAGGATTGCTTCTAC \\
84gg mutant & AGGATTGGCTTCT AC \\
IVS normal & GCATCAGGTGAGTG \\
IVS mutant & GCATCAGATGAGTGA \\
\hline
\end{tabular}

\section{Duplex PCR Reaction}

Reactions contained PCR buffer [ $33 \mathrm{~mm}$ Tris- $\mathrm{HCl}$ ( $\left.\mathrm{pH} \mathrm{8.3),} 16.7 \mathrm{mM}\left(\mathrm{NH}_{4}\right)_{2} \mathrm{SO}_{4}\right], 3$ $\mathrm{mM} \mathrm{MgCl}_{2}, 200 \mu \mathrm{m}$ each of the four deoxynucleotide triphosphates, 20-25 $\mu \mathrm{l}$ DNA, 50 pmoles each of GD1F and GD1R, 10 pmoles each of GD2F and GD2R, and 1.25 units of AmpliTaq DNA polymerase (Perkin-Elmer, Norwalk, CT) in a final volume of $50 \mu \mathrm{l}$. Temperature cycling was carried out in a Perkin-Elmer Thermal Cycler Series 9600. After 2 min at $94^{\circ} \mathrm{C}, 30$ cycles of amplification were carried out, each consisting of a 15 -sec denaturation at $94^{\circ} \mathrm{C}$ and a $50-\mathrm{sec}$ annealing/extension at $72^{\circ} \mathrm{C}$. A final 5-min extension at $72^{\circ} \mathrm{C}$ was performed.

\section{Acrylamide Gel Electrophoresis}

PCR reactions $(7.5 \mu \mathrm{l})$ were analyzed on $5 \%$ acrylamide gels (Bio-Rad Laboratories). Reaction products were UV-visualized by ethidium bromide staining.

\section{Hybridization With Labeled ASOs}

PCR reactions were diluted with $50 \mu 1$ of TE buffer [ $10 \mathrm{~mm}$ Tris- $\mathrm{HCl}(\mathrm{pH} 8), 1 \mathrm{~mm}$ EDTA] containing bromophenol blue at $5 \mu \mathrm{g} / \mathrm{ml}$. This allowed easy visualization of the DNA dots on the hybridization membrane. Of this mixture, $7.5 \mu \mathrm{l}$ was spotted on nylon membranes (AppliGene, Pleasanton, CA). Membranes were UV cross-linked (254 $\mathrm{nm}, 120 \mathrm{~mJ} / \mathrm{cm}^{2}$ ) twice for $10 \mathrm{sec}$ each in a Spectrolinker XL1000 (EM Corp., Chestnut Hill, MA) and dried at $80^{\circ} \mathrm{C}$ for $30 \mathrm{~min}$. DNA was denatured by soaking the membranes for $20 \mathrm{~min}$ in $0.2 \mathrm{~N} \mathrm{NaOH}, 0.1 \% \mathrm{SDS}$, neutralized in $2 \times$ SSC [ $1 \times$ SSC is $0.15 \mathrm{M}$ $\mathrm{NaCl}, 15 \mathrm{~mm}$ sodium citrate ( $\mathrm{pH} 7)$, and prehybridized in a hybridization oven (Bellco, Vineland, $\mathrm{NJ}$ ) at $40^{\circ} \mathrm{C}$ for $1 \mathrm{hr}$ in $5 \times$ SSC, $0.2 \%$ SDS, $2 \mathrm{mg} / \mathrm{ml}$ of Geneprint
(Promega, Madison, WI), and $1 \times$ Denhardt's solution $[0.02 \%$ (wt/vol) each of Ficoll 400, polyvinylpyrrolidone, and fraction $\mathrm{V}$ of bovine serum albumin]. The prehybridization solution was decanted and replaced with the hybridization buffer $(5 \times$ SSC, $0.2 \%$ SDS, $1 \times$ Denhardt's solution, $0.1-2$ pmoles $/ \mathrm{ml}$ labeled probe), and incubation continued for $1 \mathrm{hr}$ at $40^{\circ} \mathrm{C}$. Membranes were washed for $10 \mathrm{~min}$ in $0.8 \times$ SSC and $0.1 \%$ SDS twice at room temperature, and once at $40^{\circ} \mathrm{C}$. A final wash was performed for $10 \mathrm{~min}$ in $2 \times \mathrm{SSC}$ at room temperature.

\section{Detection of Hybridization Signals}

Hybridization membranes were washed twice, for $15 \mathrm{~min}$ each, in $100 \mathrm{~mm}$ Tris$\mathrm{HCl}(\mathrm{pH} 7.5)$ and $150 \mathrm{~mm} \mathrm{NaCl}$, followed by two 5 -min washes in $100 \mathrm{~mm}$ Tris- $\mathrm{HCl}$ (pH 9.5), $100 \mathrm{~mm} \mathrm{NaCl}$, and $50 \mathrm{~mm}$ $\mathrm{MgCl}_{2}$. Finally, blots were dipped briefly in LumiPhos 530 solution (Lumigen, South Port, MI), wrapped in plastic wrap, and incubated at $37^{\circ} \mathrm{C}$ for $15 \mathrm{~min}$. Blots were then exposed to $\mathrm{x}$-ray film (Kodak XOMAT-AR) at room temperature for 10-60 $\mathrm{min}$.

\section{RESULTS}

The PCR reaction was designed to coamplify two genomic DNA fragments containing the four most common mutations found in the Ashkenazi Jewish population (Fig. 1A). A PCR primer pair (GD1F and GD1R) amplifies a 1024-bp DNA fragment containing the loci for N370S and L444P mutations. This fragment also contains loci for four other less common missense mutations: V394L, D409H, D409V, and P415R. ${ }^{(12,13)}$ In addition, the site for a rare 55-bp deletion at nucleotides $5879-5933^{(14,15)}$ is amplified in this fragment. The second primer pair (GD2F and GD2R) amplifies a 701-bp fragment containing the loci for $84 \mathrm{gg}$ and IVS $2+1$ mutations. To prevent amplification of the highly homologous pseudogene sequences, ${ }^{(16)}$ the $3^{\prime}$ ends of the PCR primers were chosen in regions where nucleotide mismatches between the functional and pseudogenes exist. (Fig. 1B) ${ }^{(15)}$ Moreover, all primers have a theoretical $T_{m}$ of $78-80^{\circ} \mathrm{C}$, thus eliminating the need for a separate annealing step, which reduces the time required to complete the PCR cycles. Figure 2 shows the amplification products of the duplex PCR reaction using clinical specimens. The two fragments amplified efficiently and reproducibly and contained sequences derived from the functional gene only (see below).

The objective of this test was to simplify the logistics of screening for multiple mutations for a large number of clinical specimens. To achieve this goal, we designed our ASO probes (Table 1) with a $T_{\mathrm{m}}$ of $44-46^{\circ} \mathrm{C}$. Hence, regardless of the ASO being used, the hybridization reactions were carried out at the same temperature $\left(40^{\circ} \mathrm{C}\right)$. Also, all washings were performed at $40^{\circ} \mathrm{C}$. The hybridization and washing procedures required only one hybridization oven set at this temperature. Figure 3 shows the detection of carriers for all four mutations discussed here. Signals are very specific and no cross-hybridization can be detected among normal and mutant ASOs. The inability of the PCR primers to amplify pseudogene sequences homologous to the two amplified fragments of the functional gene is also demonstrated in Figure 3. The L444P ( $\mathrm{T} \rightarrow \mathrm{C}$ mutation at nucleotide 6433) and the IVS2 +1 mutations $(\mathrm{G} \rightarrow \mathrm{A}$ mutation at nucleotide 1067) are both present naturally in the glucocerebrosidase pseudogene. ${ }^{(14)}$ Yet, mutant ASOs for these two alleles failed to hybridize to amplified DNA from normal subjects, indicating the absence of pseudogene-derived products.

\section{DISCUSSION}

Although screening for genetic disorders such as GD is still controversial, it is very useful for high-risk groups, people with a family history of the disease, and symptomatic patients. ${ }^{(8,16-18)}$ There are a number of published reports on the detection of GD mutations by PCR and ASO hybridization. ${ }^{(6)}$ These generally involve individual, three-temperature PCR reactions for each mutation tested, followed by ASO hybridization at various temperatures depending on the probe used. Another test was described recently in which a duplex PCR reaction similar to the one described here is followed by hybridization to individual ASOs at different temperatures. ${ }^{(19)}$ ASO hybridization at different temperatures obviously is cumbersome and time-consuming, especially when several mutations are being analyzed. Thus, none of these tests is 


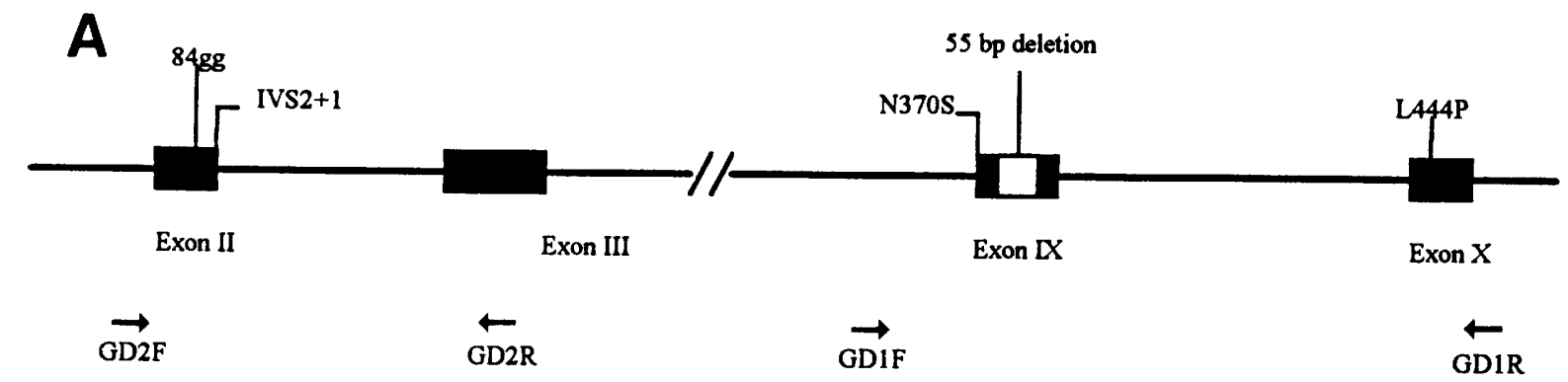

$$
\begin{aligned}
& \text { B } \\
& \text { GD1F } \\
& 5^{\prime} \text {-СCTCTTACTAGTTTCACCAAAGACTGAC-3' } \\
& \text { Functional Gene } \\
& \text { Pseudogene }
\end{aligned}
$$

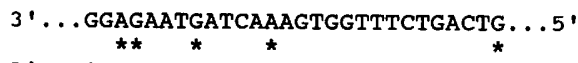

$$
\begin{aligned}
& \text { GD1R } \\
& \text { 3'...gGgTAATCATCAGAgTGgTTTCTGACTA... 5' } \\
& \text { Functional Gene } \\
& \text { Pseudogene } \\
& 5^{\prime} \text {-TCACCATTGCCCTCACCGGTTTAGC-3' } \\
& \text { GD2F } \\
& \text { Functional Gene } \\
& \text { Pseudogene } \\
& \text { GD2R } \\
& \text { Functional Gene } \\
& \text { Pseudogene } \\
& 3 ' \text {.... AgtGgtaAcGgGagtGGCCAAATCG....5' } \\
& \text { 3'... AgtGgtaAcGgGagtGgCCAAATCC...5' } \\
& 5 \text { '-TCCTCAGGAATGTCCCAAGCCTTTGA-3' } \\
& 3 \text { '... AgGAGTCCTTACAGgGTTCGGAAACT....5' } \\
& \text { 3'... AGGAGTCCTTACAGGGTTCGGAAGCC...5 ' } \\
& 5^{\prime} \text {-GACACACACCACCGAGCTGTAGCC-3' } \\
& \text { 3' ... CTGTGTGTGGTGGCTCGACATCGg... 5' } \\
& \text { 3'... CTGTGTGTGGTGGCTCGACAT-GA...5' }
\end{aligned}
$$

FIGURE 1 Duplex PCR amplification strategy. ( $A$ ) The relative locations of the PCR primers is shown. Thin lines represent sequences that are deleted in the pseudogene. $(B)$ Nucleotide sequence alignment of the PCR primers with the functional and pseudogenes. Note that the $3^{\prime}$-terminal nucleotide of all four primers does not match with the pseudogene at that position, thus, preventing pseudogene sequences from being amplified. (*) Nucleotide mismatches.

well-suited for screening large numbers of clinical specimens.

In this report we describe a new PCR/ ASO-based test for detection of GD mutations, which is designed specifically for mass screening of specimens. DNA is first extracted from a small volume of whole blood, and segments of the DNA where mutation sites reside are amplified in a single tube by a two-temperature duplex PCR. By eliminating the need for annealing at lower temperature

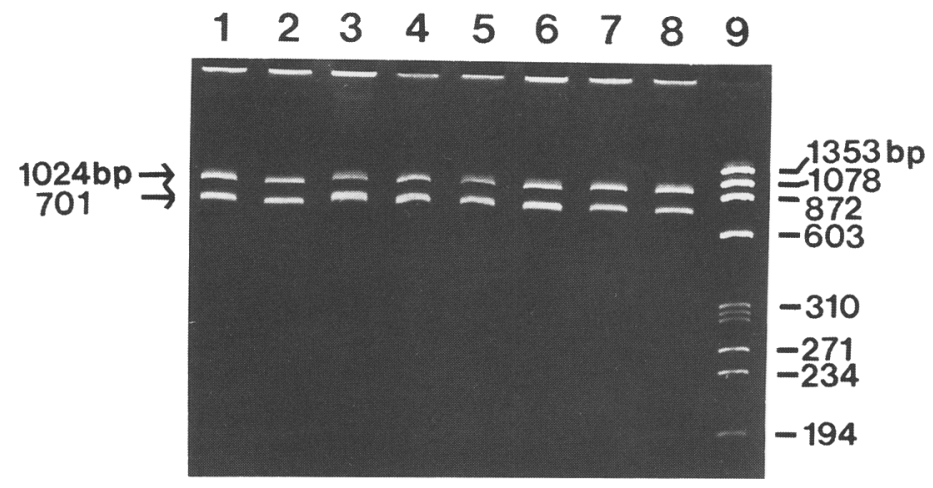

FIGURE 2 Acrylamide gel electrophoresis of the PCR amplification products. Samples of PCR reactions from several clinical specimens (lanes $1-8$ ) were analyzed on $5 \%$ nondenaturing acrylamide gel as described in Materials and Methods. The two amplified fragments are indicated by arrows. (Lane 9) Haelll restriction digest of phage $\phi X 174$ DNA.

we reduced the time required for the reaction and, more importantly, increased the specificity of the PCR primers. Specificity is increased further by PCR primers that do not amplify pseudogene sequences. As mentioned earlier, the IVS2 +1 , L444P, and deletion mutations exist naturally in the pseudogene. ${ }^{(14,15)}$ Coamplification of any pseudogene sequences therefore will complicate interpretation of results. This problem was avoided by having the PCR primers end with a nucleotide mismatch between the functional gene and pseudogene, thus, preventing primer extension of the pseudogene sequence by Taq DNA polymerase.

An important feature of this test is that detection of normal and mutant alleles is carried out by hybridization to ASOs at a single temperature $\left(40^{\circ} \mathrm{C}\right)$. Also, all subsequent washings are performed at $40^{\circ} \mathrm{C}$. Moreover, testing for cystic fibrosis (CF) mutations that are common in Jewish populations is carried 


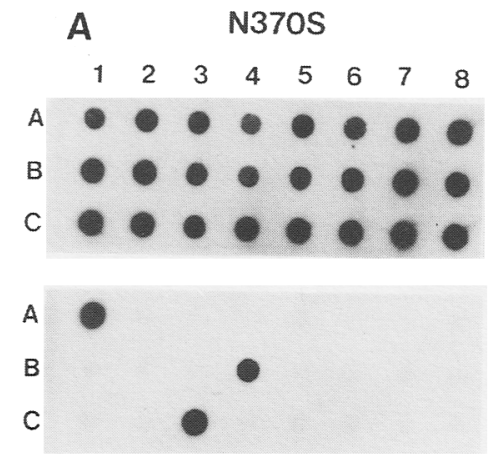

IVS $2+1$
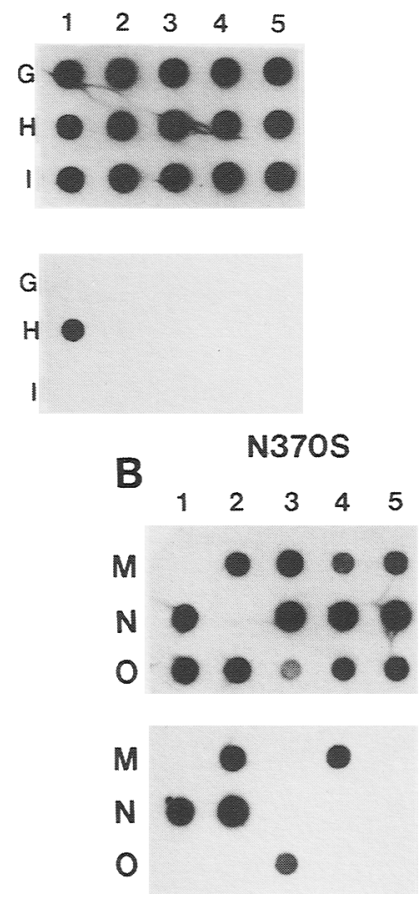
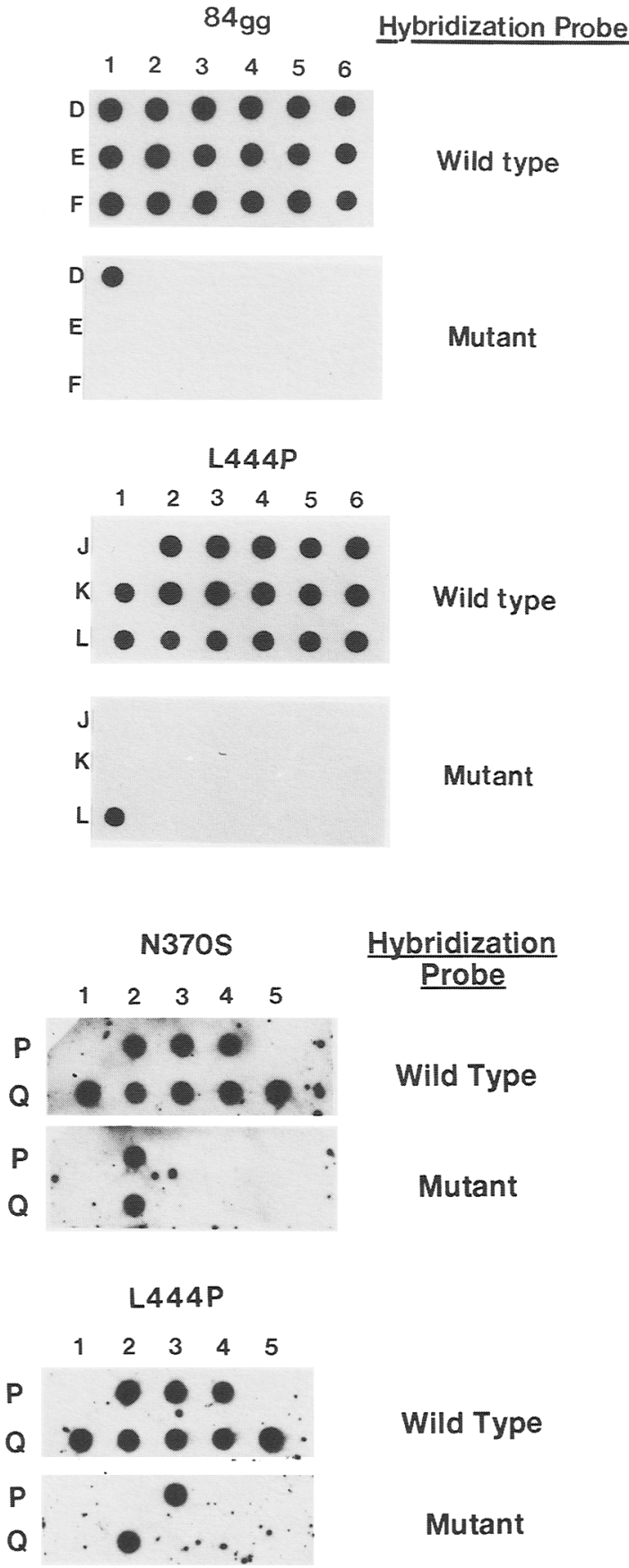

FIGURE 3 ASO hybridization analysis of GD mutations. Products of the duplex PCR reactions were spotted on nylon membranes, fixed by UV cross-linking, dried, and hybridized to alkaline phosphatase-conjugated ASOs (see Materials and Methods). Duplicate membranes were spotted for each mutations analyzed. One membrane in each set was hybridized to wild-type ASO (top), the other membrane was hybridized to mutant ASO (bottom). $(A)$ Detection of heterozygous carriers. Patients A1, B4, and C3 are carriers for the N370S mutation. Patients D1, H1, and L1, on the other hand, are carriers for the $84 \mathrm{gg}$, IVS2 +1 , and L444P mutations, respectively. The rest of the positions are normal subjects with the exception of position $\mathrm{J1}$, which is a negative control (no DNA). (B) Detection of homozygous (N2) and compound heterozygous (Q2) affected patients. Patients M2, M4, N1, O3, and P2 are carriers for N370S. Patient P3 is a carrier for L444P.

out in our laboratories by ASO hybridization at $40^{\circ} \mathrm{C}$. Because GD is often requested along with CF tests, our test has significantly simplified the logistics of routine screening of hundreds of clinical specimens for both genetic disorders.

The use of alkaline phosphatase-conjugated probes in this test eliminates the need for a second blocking step and additional incubation with antibody. Total analysis time (post-PCR) for all four mutations is $\sim 3 \mathrm{hr}$. Finally, results obtained by this test are easy to interpret. As the data presented here show, normal subjects and heterozygous carriers can be identified easily. Homozygous patients (where only the normal ASO would hybridize), as well as compound heterozygous patients (where both normal and mutant ASOs would hybridize), also can be identified on $\mathrm{X}$-ray films (Fig. 3). Identification of carriers is particularly useful in providing genetic counseling for high-risk individuals.

\section{ACKNOWLEDGMENTS}

We thank Dr. Gayle Rosner for her contribution at the initial stages of this work, and Dr. Ted Mifflin for his valuable discussions throughout the duration of this project. Funding was provided by U.S. Public Health Service grant DK43709 to J.A.B., and the Pathology Education and Research Foundation (PERF).

\section{REFERENCES}

1. Barranger, J.A. and E.I. Ginns. 1989. Glucosylceramide lipidoses: Gaucher disease. In The metabolic basis of inherited diseases (ed. C.R. Scriver, A.L. Beaudet, W.S. Sly, and D. Valle), pp. 1677-1699. McGrawHill, New York.

2. Grabowski, G.A., S. Gatt, and M. Horowitz. 1990. Acid beta-glucosidase: Enzymology and molecular biology of Gaucher disease. Crit. Rev. Biochem. Mol. Biol. 25: 385-414.

3. Beutler, E. 1991. Gaucher's disease. New Engl. J. Med. 325: 1354-1360.

4. Zimran, A., T. Gelbart, B. Westwood, G.A. Grabowski, and E. Beutler. 1991. High frequency of the Gaucher disease mutation at nucleotide 1226 among Ashkenazi Jews. Am. J. Hum. Genet. 49: 855-859.

5. Zimran, A., E. Gross, C. West, J. Sorge, M. Kubitz, and E. Beutler. 1989. Prediction of severity of Gaucher's disease by identification of mutations at DNA level. Lancet 2: 349-352.

6. Hong, C.M., T. Ohashi, X.J. Yu, S. Weiler, and J.A. Barranger. 1990. Sequence of two alleles responsible for Gaucher disease. DNA Cell Biol. 9: 233-241.

7. Tsuji, S., B.M. Martin, J.A. Barranger, B.K. Stubblefield, M.E. LaMarca, and E.I. Ginns. 1988. Genetic heterogeneity in type 1 Gaucher disease: Multiple genotypes in Ashkenazic individuals. Proc. Natl. Acad. Sci. 85: 2349-2352. 
8. Beutler, E., T. Gelbart, W. Kuhl, J. Sorge, and C. West. 1991. Identification of the second common Jewish Gaucher disease mutation makes possible populationbased screening for the heterozygous state. Proc. Natl. Acad. Sci. 88: 1054410547.

9. Tsuji, S., P.V. Choudary, B. Martin, B.R. Stubblefield, J.A. Mayor, J.A. Barranger, and E.I. Ginns. 1987. A mutation in the human glucocerebrosidase gene in neuropathic Gaucher's disease. N. Engl. I. Med. 316: 570-575.

10. Beutler, E., T. Gelbart, W. Kuhl, A. Zimran, and C. West. 1992. Mutations in Jewish patients with Gaucher disease. Blood 79: 1662-1666.

11. He, G.S. and G.A. Grabowski. 1992 Gaucher disease: $A$ G $+1-A+1$ IVS2 splice donor site mutation causing exon 2 skipping in the acid beta-glucosidase mRNA. Am. I. Hum. Genet. 51: 810-820.

12. Theophilus, B.D., T. Latham, G.A. Grabowski, and F.I. Smith. 1989. Comparison of RNase A, a chemical cleavage and GC-clamped denaturing gradient gel electrophoresis for the detection of mutations in exon 9 of the human acid beta-glucocerebrosidase gene. Nucleic Acids Res. 17: 7707-7722.

13. Wigderson, M., N. Firon, Z. Horowitz, S. Wilder, Y. Frishberg, O. Reiner, and M. Horowitz. 1989. Characterization of mutations in Gaucher patients by cDNA cloning. Am. J. Hum. Genet. 44: 365-377.

14. Beutler, E. 1992. Gaucher disease: New molecular approaches to diagnosis and treatment. Science 256: 794-799.

15. Horowitz, M., S. Wilder, Z. Horowitz, O. Reiner, T. Gelbart, and E. Beutler. 1989. The human glucocerebrosidase gene and pseudogene: Structure and evolution. Genomics 4: 87-96.

16. Sidransky, E. and E.I. Ginns. 1994. Phenotypic and genotypic heterogeneity in Gaucher disease: Implications for genetic counseling. J. Genet. Counsel. 3: 13-22.

17. Horowitz, M., G. Tzuri, N. Eyal, A. Berebe, E.H. Kolodny, R.O. Brady, N. Barton, A. Abrahamov, and A. Zimran. 1993. Prevalence of nine mutations among Jewish and non-Jewish Gaucher disease patients. Am. J. Hum. Genet. 53: 921-930.

18. Rice, E.O., R.E. Lee, S.A. Sakallah, T.E. Miffen, C.A. Sanseiri, and J.A. Barranger, in prep.

19. Beutler, E., N.J. Nguyen, M.W. Henneberger, J.M. Smolec, R.A. McPherson, C. West, and T. Gelbart. 1993. Gaucher disease: Gene frequencies in the Ashkenazi Jewish population. Am. J. Hum. Genet. 52: 85-88.

Received May 17, 1994; accepted in revised form June 24, 1994. 


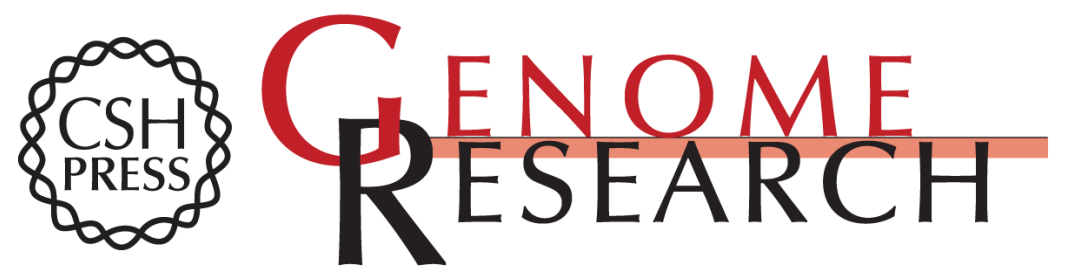

\section{A new diagnostic test for Gaucher disease suitable for population screening.}

S A Sakallah, C Sansieri, D W Kopp, et al.

Genome Res. 1994 4: 1-5

References This article cites 17 articles, 4 of which can be accessed free at: http://genome.cshlp.org/content/4/1/1.full.html\#ref-list-1

License

Email Alerting

Receive free email alerts when new articles cite this article - sign up in the box at the Service top right corner of the article or click here.

\section{Affordable, Accurate Sequencing.}

To subscribe to Genome Research go to: https://genome.cshlp.org/subscriptions 